\title{
Effects of feed refreshing frequency on growth and carcass characteristics of Awassi lambs
}

\author{
M. Keskin ${ }^{\#}$, S. Gül, A. Şahin, Ş. Kaya, M. Duru, Ö. Görgülü, S. Sahinler and O. Biçer \\ Mustafa Kemal University, Agriculture Faculty, Dept. of Animal Science, Hatay, Turkey
}

\begin{abstract}
Sixty, two-month old male Awassi lambs were used in this study to investigate the effects of feed refreshing (FR) frequencies on their growth and carcass characteristics over a period of 65 days. Treatments were: Feed refreshing at $2 \mathrm{~h}$ (FR2), $4 \mathrm{~h}$ (FR4), $8 \mathrm{~h}$ (FR8), $12 \mathrm{~h}$ (FR12) and $24 \mathrm{~h}$ (FR24) intervals. The lambs were fed individually. At the onset of each refreshing period the lambs were offered fresh feed ad libitum. Daily feed intakes, weekly live weights and carcass characteristics were recorded. Daily feed intakes per lamb per treatment were: $1.13 \mathrm{~kg}, 1.05 \mathrm{~kg}, 1.00 \mathrm{~kg}, 0.98 \mathrm{~kg}$ and $0.95 \mathrm{~kg}$; daily gains were $193.6 \mathrm{~g}, 180.6 \mathrm{~g}$, $148.6 \mathrm{~g}, 169.3 \mathrm{~g}$ and $146.4 \mathrm{~g}$; feed conversion ratios ( $\mathrm{kg}$ feed $/ \mathrm{kg}$ gain) were 6.1, 6.7, 7.2, 7.2 and 7.5; hot carcass weights were $13.0 \mathrm{~kg}, 13.1 \mathrm{~kg}, 12.1 \mathrm{~kg}, 13.3 \mathrm{~kg}$ and $13.1 \mathrm{~kg}$; dressing percentages were $42.3 \%$, $42.4 \%, 39.9 \%, 40.2 \%$ and $41.2 \%$; the proportion of muscle in the carcass was $52.0 \%, 55.2 \%, 55.6 \%, 55.8 \%$ and $54.8 \%$; bone ratio was $20.4 \%, 20.3 \%, 21.9 \%, 21.1 \%$ and $20.9 \%$; subcutaneous fat ratio was $16.9 \%$, $14.2 \%, 12.9 \%, 12.7 \%$ and $14.0 \%$ and intramuscular fat ratio was $8.8 \%, 7.1 \%, 6.8 \%, 8.7 \%$ and $7.7 \%$ in FR2, FR4, FR8, FR12 and FR24 treatments, respectively. Results showed that frequent feed refreshing stimulated feed intake and daily gain without affecting carcass characteristics.
\end{abstract}

Keywords: Lamb, feeding system, daily gain, body components

\#Corresponding author. E-mail: mkeskin@mku.edu.tr, mkeskinmku@gmail.com

\section{Introduction}

Similar to other farm species, fattening characteristics of lambs vary with feeding system (e.g. a meal or an ad libitum system). Previous studies showed that weight gains were better under ad libitum feeding systems than in controlled feeding systems (Eliçin et al., 1983; Priolo et al., 2002; Santos-Silva et al., 2002). Animals can match their nutrient requirements through voluntary intake when fed ad libitum. Conventionally, feeding units using ad libitum systems use feed troughs that contain sufficient feed to meet the requirements of the animals for a few days. However, feed in feed troughs usually gets contaminated and wet with animal saliva which can cause the feed to harden. Consequently animals tend to resist consuming the feed. For this reason, many livestock producers prefer the meal system for finishing. However, the frequency of meals should be investigated based on animal needs and welfare. Effects of feeding frequencies on milk production and ruminal physiology have been investigated in dairy cows (Yang \& Varga, 1989; Liboux \& Peyraud, 1999; Shabi et al., 1999; Van den Borne et al., 2006). Keskin et al. (2004) observed that Awassi lambs increased their feed intake when they were offered fresh feed even when there was feed in their feed troughs. It was postulated that increased meal frequency with fresh feed would promote the appetite of lambs and have an influence on their finishing performance and carcass weights. In previous studies (Yang \& Varga, 1989; Liboux \& Peyraud, 1999; Shabi et al., 1999; Van den Borne et al., 2006) meal frequency referred to the frequency with which animals actually consume feed, not to the frequency with which animals were presented with fresh feed. The literature is inconclusive on the effect of feed refreshening on the growth performance and carcass characteristics of lambs. Therefore, the present study was aimed at investigating the effects of feed refreshing frequency on growth and carcass characteristics when an ad libitum feed intake was ensured.

\section{Material and Methods}

Sixty single born, fat-tailed male Awassi lambs were used in the study, conducted at the Research and Training Farm of the Mustafa Kemal University in Hatay. This province is located between $36^{\circ} \mathrm{N}$ latitude and $36^{\circ} \mathrm{E}$ longitude in the eastern Mediterranean region of Turkey where climatic conditions are hot and dry in summer and warm and rainy in winter. The study was conducted in the summer. 
At the onset of the study the lambs were two months old with an average live weight of $21.7 \pm 0.41$ $\mathrm{kg}$. After a 15-day adaptation period, the lambs were numbered. These lambs were ranked into randomised blocks according to body weight, and within blocks randomly allocated to five treatment groups (12 lambs per group) to ensure approximately equal body weights per treatment at the onset of the study. The lambs were housed individually in $100 \times 120 \times 120 \mathrm{~cm}$ pens in semi-open sheds and were subjected to continuous lighting and an ambient temperature ranging from $19.1{ }^{\circ} \mathrm{C}$ during the night to $35.3{ }^{\circ} \mathrm{C}$ during the day.

Feed refreshing encompassed the replacing of all feed offered, and this was performed at different intervals during the day for the different treatments. Treatments were: feed was replaced at $2 \mathrm{~h}$ (FR2), $4 \mathrm{~h}$ (FR4), $8 \mathrm{~h}$ (FR8), $12 \mathrm{~h}$ (FR12) or $24 \mathrm{~h}$ (FR24) intervals. The FR24 treatment, or once a day feeding, was considered the control. At the end of each feeding interval the lambs were offered fresh feed ad libitum after left-overs from the previous meal were removed and weighed back. Daily feed intake was obtained by adding the feed consumption of each lamb during each interval over a $24 \mathrm{~h}$ period. The experimental diet (Table 1) was prepared based on the nutritional requirements of lambs (NRC, 1985) and all lambs had free access to fresh water. The lambs were vaccinated against enterotoxaemia before the experiment and injected with vitamins $\mathrm{A}, \mathrm{D}$ and $\mathrm{E}$.

Lambs were weighed individually on the same day each week, and individual feed intakes were recorded daily for 56 days. Feed conversion ratio per week was calculated by dividing total feed intake by live weight gain during the week.

At the end of the experiment three lambs representing the average live weight per group were selected from each group to determine carcass characteristics. After 12 hours of feed deprivation, these lambs were weighed and slaughtered humanely. Body parts (head, legs, skin, lungs, liver, heart, kidneys, kidneys and pelvis fat, spleen and testis) and hot carcasses were weighed immediately after slaughtering. All carcasses were refrigerated at $4{ }^{\circ} \mathrm{C}$ for 24 hours to determine cold carcass weight and dressing percentage. Each carcass was dissected according to the Mediterranean Countries Standard Method and relative weights of different joints as well as the relative weights of muscle, bone and fat tissue were determined within the different joints (Colomer-Rocher et al., 1987).

Table 1 Composition of the diet given to the experimental lambs

\begin{tabular}{lc}
\hline Ingredients (/kg) & $\mathrm{g} / \mathrm{kg}$ \\
\hline Barley (890 g DM, 12.3 MJ ME, 110.4 g CP, 49 g CF) & 480 \\
Wheat bran (910 g DM, 10.7 MJ ME, 130 CP, 76 CF) & 180 \\
Cotton seed meal (900 g DM, 8.5 MJ ME, 319.5 g CP, 129.6 g CF) & 220 \\
Lucerne straw (850 g DM, 6.4 MJ ME, 150 g CP, 290 g CF) & 100 \\
Salt & 10 \\
Vitamin \& mineral mixture (obtained from a commercial source) & 10 \\
Calculated composition per kg fresh diet & 887 \\
Dry matter (DM), g & 10.3 \\
Metabolisable energy (ME) MJ & 161 \\
Crude protein (CP), g & 95 \\
Crude fibre (CF), g & 64 \\
Ash, g & 8 \\
Ca, g & 6 \\
P,g & 6 \\
Na, g & 7 \\
\hline
\end{tabular}


Statistical analyses for the main effect of feed refreshing frequency on growth and carcass characteristics were done using analysis of variance by using initial body weights of the lambs as covariants (Multivariate Analysis of Variance) and Duncan Multiple Range Test in SPSS program (Windows version of SPSS, release 10.01).

\section{Results and Discussion}

Daily feed intake, daily gain and feed conversion ratios are given in Table 2 and Figures 1 and 2.

Table 2 Effect of feed refreshing frequencies on some finishing performance parameters (mean \pm standard error)

\begin{tabular}{|c|c|c|c|c|c|c|}
\hline \multirow[b]{2}{*}{ Parameters, per lamb } & \multicolumn{6}{|c|}{ Treatment groups } \\
\hline & FR2 & FR4 & FR8 & FR12 & FR24 & $\mathrm{P}$ \\
\hline Initial body weight, $\mathrm{kg}$ & $21.4 \pm 0.8$ & $21.7 \pm 1.2$ & $21.5 \pm 0.7$ & $21.7 \pm 0.9$ & $22.3 \pm 1.1$ & NS \\
\hline Daily feed intake, $\mathrm{kg}$ & $1.13^{\mathrm{a}} \pm 0.03$ & $1.05^{\mathrm{ab}} \pm 0.04$ & $1.00^{\mathrm{b}} \pm 0.03$ & $0.98^{b} \pm 0.03$ & $0.95^{b} \pm 0.03$ & $* *$ \\
\hline Daily gain, $\mathrm{g}$ & $193.6^{\mathrm{a}} \pm 10.7$ & $180.6^{\mathrm{a}} \pm 10.5$ & $148.6^{b} \pm 9.3$ & $169.3^{\mathrm{ab}} \pm 9.4$ & $146.4^{\mathrm{b}} \pm 9.9$ & $* *$ \\
\hline FCR (feed/gain) & $6.1 \pm 0.2$ & $6.7 \pm 0.4$ & $7.2 \pm 0.2$ & $7.2 \pm 0.5$ & $7.5 \pm 0.4$ & NS \\
\hline
\end{tabular}

P - statistical significance: ${ }^{* *}-\mathrm{P}<0.01$; NS - non significant; ${ }^{\mathrm{a}-\mathrm{b}}$ - Different superscripts in same row indicate statistical significance; FR (2-24) - offering fresh feed every $2 \mathrm{~h}, 4 \mathrm{~h}, 8 \mathrm{~h}, 12 \mathrm{~h}$ and $24 \mathrm{~h}$, respectively

From Table 2 it is evident that lambs in FR2 consumed more $(\mathrm{P}<0.01)$ feed than those in the FR 8 and less frequently fed groups. This could be attributed to the fact that increased feeding frequency tends to increase feed passage through the gastrointestinal tract (Merchen, 1988; Forbes, 1995). This result might have reduced feed digestibility, which would influence FCR negatively. In this study, feed intake was higher, though FCR was not affected significantly, suggesting that the increased nutrient availability was greater than the decrease in digestibility. Seeing and smelling fresh feed and being conditioned by the presence of the stockman feeding them could have stimulated their appetite, as reported by Keskin et al. (2004). The more frequent feeding regimens as practised in treatments FR2 and FR4 resulted in increased daily gains compared to the other treatments $(\mathrm{P}<0.01)$. This might be attributed to a stimulation of the gastrointestinal system, the saliva glands and/or rumen secretions (Özen, 1995). Furthermore, feed refreshing at the 2-hour and 4-hour intervals might have affected ruminal comfort positively, as reported by Shabi et al. (1998). They found that the fluctuation in ruminal ammonia-N concentrations was lower when cows were fed four times a day compared to twice a day. Demirören (2002) reported that lambs fed eight times a day, between 9:30 and 15:15, had higher daily gains than those fed once a day. Also, an increase in feeding frequency in dairy cows enhanced total DM digestibility in the study of Shabi et al. (1999). This might be true also for growth performance in the present study. However, the mechanical effects of feed refreshing may have increased food transit time but this should be investigated in further studies.

In the present study, daily feed intakes and gains were lower than expected. This could be due to individual housing without any competition between lambs, which can affect growth adversely, as reported by Fraser \& Broom (1990) and Forbes (1995). Feeding a diet consisting of $75 \%$ concentrates, Goetsch \& Galyean (1983) found that the molar proportions of ruminal acetate and butyrate were higher and propionate lower in beef steer fed eight times a day compared to those fed twice a day. Unfortunately volatile fatty acid concentrations of rumen fluid were not measured in the present study.

Time-dependent feed intakes of the experimental lambs during the finishing period are depicted in Figure 1. Feed intake increased until the third week of the finishing period, though daily gains and feed intakes were lower than those reported by Keskin et al. (2005) on Awassi lambs in the same region. This could be due to seasonal difference, since the study of Keskin et al. (2005) was conducted in the winter season. It is well documented that high temperatures adversely affect feed intake and daily gain (McDonalds et al., 1995). 


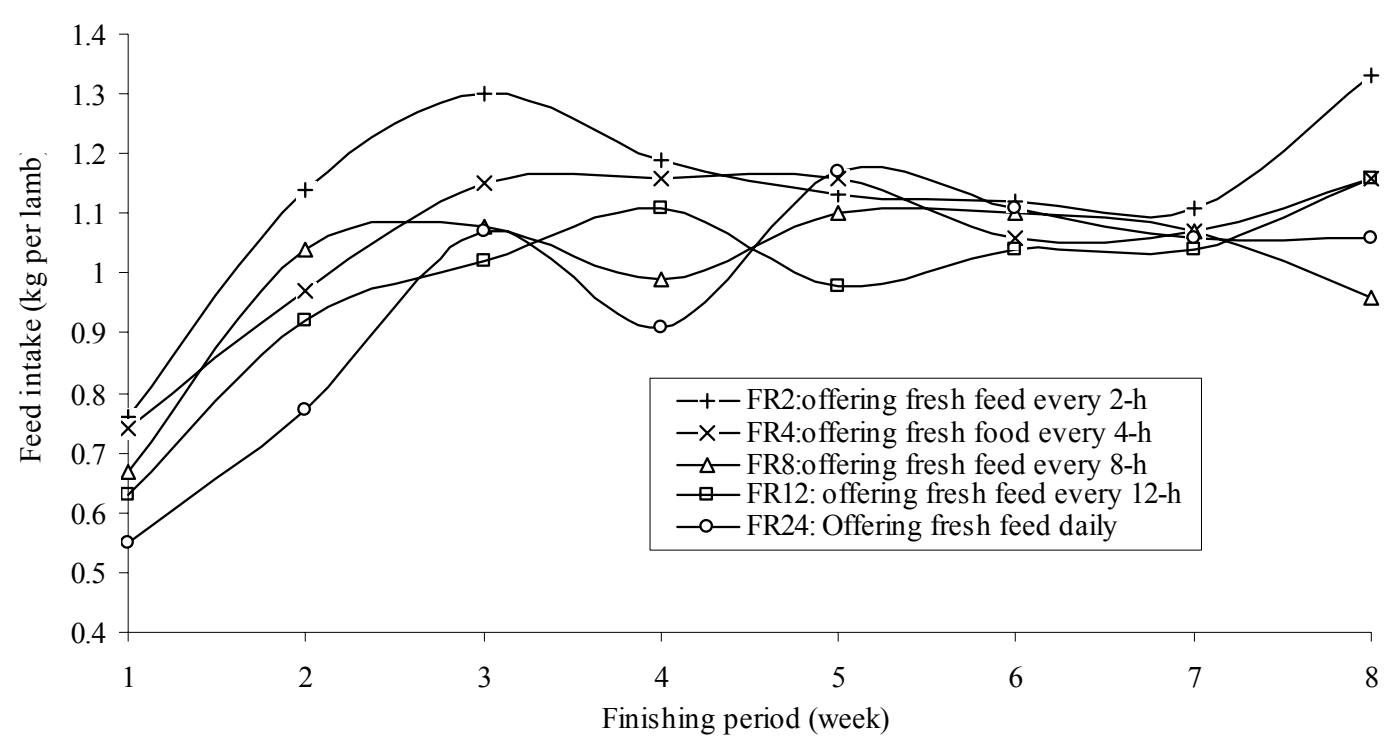

Figure 1 Feed intakes of experimental lambs during the finishing period

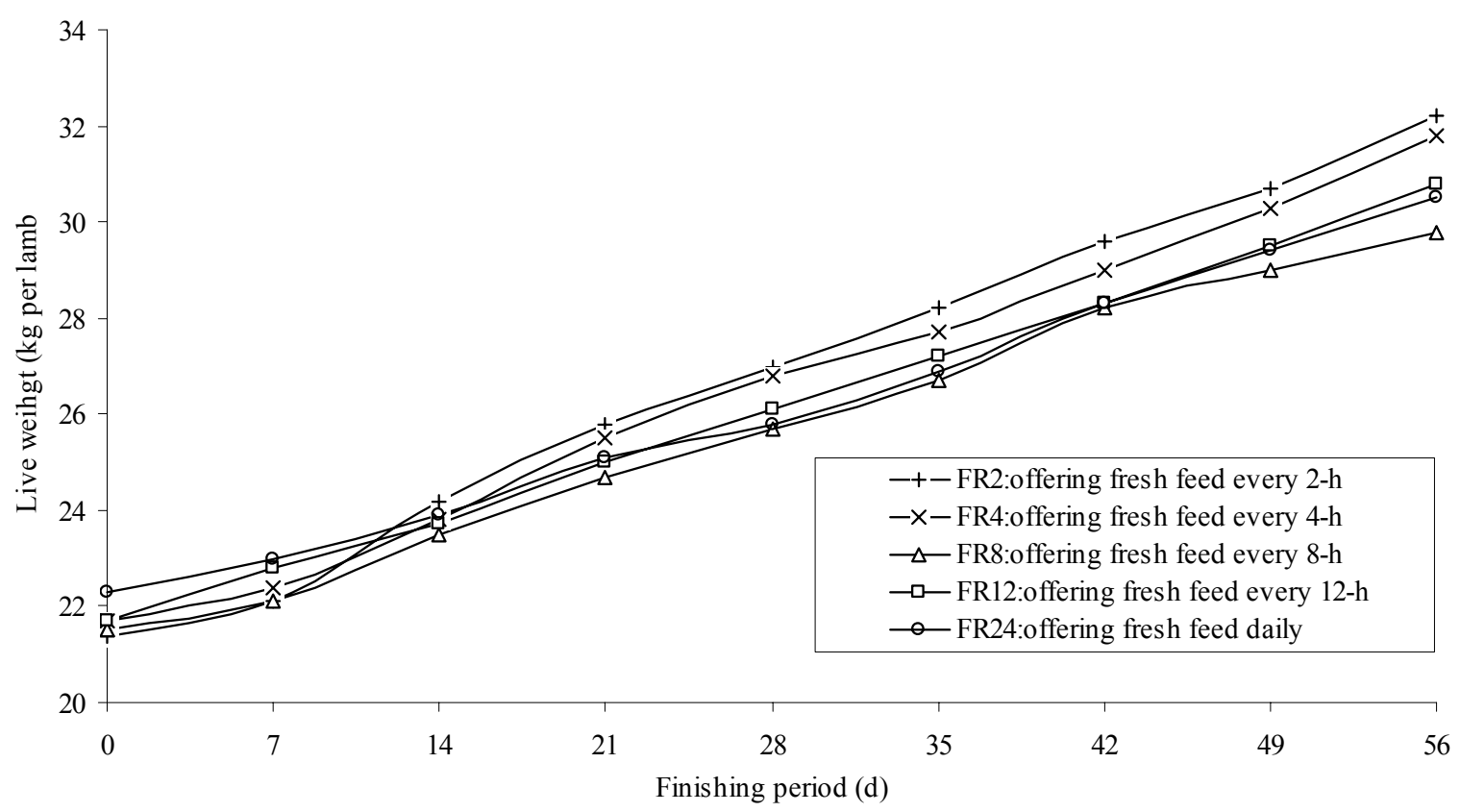

Figure 2 Live weights of experimental lambs during the finishing period

Live weight changes in the experimental lambs are presented in Figure 2, demonstrating that the FR2 lambs exhibited the highest live weight gains. Daily weight gains of lambs on a weekly basis are illustrated in Figure 3. Lambs in FR4 had the lowest daily gain during the study. Feed conversion ratios (feed : gain) are presented in Table 3. Differences between treatments were not significant.

Three representative lambs from each group were slaughtered at day 56 day of the study and dissected after $24 \mathrm{~h}$. No differences were measured between treatments in carcass components (Table 4) and tissue composition of dissected parts (Table 5). The only exception was skin weight where differences were reported though it did not follow a specific trend. 
Table 3 Effects of feed refreshing frequency on feed conversion ratio (feed/gain) during finishing period

\begin{tabular}{ccccccccc}
\hline $\begin{array}{c}\text { Fattening } \\
\text { period }\end{array}$ & \multicolumn{7}{c}{ Treatment groups } \\
\cline { 2 - 8 } $0-7 \mathrm{~d}$ & 12 & 9.1 & 11.5 & 9.5 & 9.8 & 11.4 & 1.095 & NS \\
$0-14 \mathrm{~d}$ & 12 & 5.1 & 6.3 & 6.5 & 9.7 & 7.2 & 0.707 & $\mathrm{NS}$ \\
$0-21 \mathrm{~d}$ & 12 & 5.4 & 5.5 & 6.6 & 6.6 & 6.3 & 0.329 & $\mathrm{NS}$ \\
$0-28 \mathrm{~d}$ & 12 & 5.8 & 5.8 & 6.8 & 6.7 & 6.9 & 0.320 & $\mathrm{NS}$ \\
$0-35 \mathrm{~d}$ & 12 & 5.8 & 6.2 & 7.1 & 6.4 & 7.3 & 0.271 & $\mathrm{NS}$ \\
$0-42 \mathrm{~d}$ & 12 & 5.8 & 6.2 & 6.7 & 6.2 & 7.2 & 0.234 & $\mathrm{NS}$ \\
$0-49 \mathrm{~d}$ & 12 & 5.9 & 6.1 & 7.0 & 6.2 & 7.0 & 0.212 & $\mathrm{NS}$ \\
$0-56 \mathrm{~d}$ & 9 & 6.0 & 6.1 & 7.1 & 6.1 & 7.1 & 0.214 & $\mathrm{NS}$ \\
\hline
\end{tabular}

P - statistical significance: NS - non significant; SED - standard error difference of means FR (2-24) - offering fresh feed every $2 \mathrm{~h}, 4 \mathrm{~h}, 8 \mathrm{~h}, 12 \mathrm{~h}$ and $24 \mathrm{~h}$, respectively

Table 4 Effect of different feed refreshing frequency on different carcass components of lambs

\begin{tabular}{|c|c|c|c|c|c|c|c|}
\hline \multirow[b]{2}{*}{ Parameters, per lamb } & \multicolumn{7}{|c|}{ Treatments } \\
\hline & FR2 & FR 4 & FR 8 & FR 12 & FR 24 & SED & $\mathrm{P}$ \\
\hline Slaughter weight, (kg) & 30.2 & 30.0 & 29.5 & 32.2 & 31.1 & 0.39 & NS \\
\hline Hot carcass weight, (kg) & 13.0 & 13.1 & 12.1 & 13.3 & 13.1 & 0.21 & NS \\
\hline Cold carcass weight, (kg) & 12.8 & 12.7 & 11.8 & 13.0 & 12.8 & 0.20 & NS \\
\hline Dressing \% (Hot carcass) & 44.4 & 43.5 & 41.2 & 41.2 & 42.2 & 0.57 & NS \\
\hline Dressing \% (Cold carcass) & 42.3 & 42.4 & 39.9 & 40.2 & 41.2 & 0.45 & NS \\
\hline \multicolumn{8}{|l|}{ Carcass Components: } \\
\hline Head (kg) & 2.5 & 2.1 & 1.9 & 1.8 & 2.0 & 0.12 & NS \\
\hline 4 feet $(\mathrm{kg})$ & 1.1 & 0.8 & 0.7 & 0.8 & 0.7 & 0.08 & NS \\
\hline Skin (kg) & $3.5^{\mathrm{ab}}$ & $3.6^{\mathrm{abc}}$ & $3.3^{\mathrm{a}}$ & $3.8^{\mathrm{c}}$ & $3.7^{b c}$ & 0.06 & $*$ \\
\hline Kidneys, (g) & 70.0 & 73.3 & 73.3 & 70.0 & 90.0 & 3.63 & NS \\
\hline Kidney \& knob fat, (g) & 143.3 & 150.0 & 136.7 & 146.7 & 136.7 & 3.96 & NS \\
\hline Tail (kg) & 1.6 & 1.8 & 1.3 & 1.0 & 1.4 & 0.13 & NS \\
\hline Lung (g) & 476.0 & 560.0 & 430.0 & 450.0 & 463.3 & 18.77 & NS \\
\hline Liver $(\mathrm{g})$ & 503 & 563.3 & 516.7 & 596.7 & 540.0 & 13.34 & NS \\
\hline Heart (g) & 163.3 & 156.7 & 156.7 & 183.3 & 160.0 & 4.66 & NS \\
\hline Spleen (g) & 76.7 & 90.0 & 100.0 & 56.7 & 60.0 & 9.03 & NS \\
\hline Testis (g) & 56.7 & 60.0 & 53.3 & 40.0 & 50.0 & 3.68 & NS \\
\hline
\end{tabular}

P - statistical significance: * - P $<0.05$; Different superscripts in same row indicate statistical significance SED - standard error difference of means

FR (2-24) - offering fresh feed every $2 \mathrm{~h}, 4 \mathrm{~h}, 8 \mathrm{~h}, 12 \mathrm{~h}$ and $24 \mathrm{~h}$, respectively 


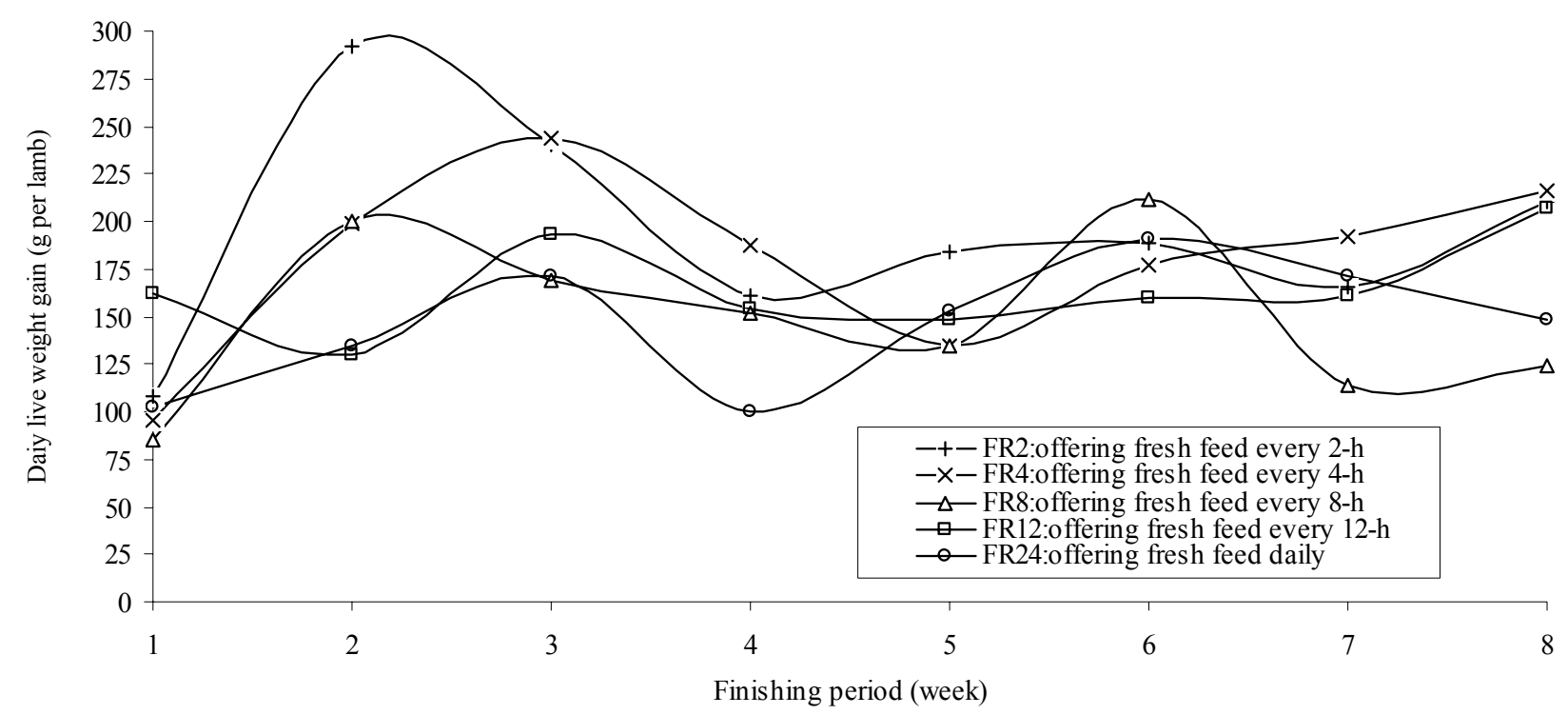

Figure 3 Daily gain of experimental lambs during the finishing period

Table 5 Effect of different feed refreshing frequencies on percentage of different tissues in different carcass components of finishing lambs at slaughter

\begin{tabular}{|c|c|c|c|c|c|c|c|}
\hline \multirow{2}{*}{$\begin{array}{l}\text { Carcass components } \\
(\%)\end{array}$} & \multicolumn{7}{|c|}{ Groups } \\
\hline & FR2 & FR 4 & FR 8 & FR 12 & FR 24 & SED & $\mathrm{P}$ \\
\hline Neck & 5.8 & 6.0 & 6.2 & 4.8 & 5.5 & 0.26 & $\mathrm{NS}$ \\
\hline Bone & 1.7 & 1.8 & 1.9 & 1.3 & 1.6 & 0.08 & NS \\
\hline Lean & 3.0 & 3.2 & 3.3 & 3.0 & 2.9 & 0.22 & NS \\
\hline Subcutaneous fat & 0.5 & 0.3 & 0.4 & 0.3 & 0.5 & 0.04 & NS \\
\hline Intramuscular fat & 0.4 & 0.3 & 0.1 & 0.2 & 0.3 & 0.04 & NS \\
\hline Shoulder & 19.0 & 18.7 & 19.4 & 19.1 & 18.2 & 0.26 & NS \\
\hline Bone & 4.1 & 4.4 & 4.0 & 4.1 & 4.1 & 0.11 & NS \\
\hline Lean & 10.6 & 11.2 & 11.8 & 11.4 & 10.6 & 0.23 & NS \\
\hline Subcutaneous fat & 2.4 & 1.7 & 1.4 & 1.7 & 1.6 & 0.15 & NS \\
\hline Intramuscular fat & 1.5 & 1.3 & 1.5 & 1.7 & 1.1 & 0.12 & NS \\
\hline Ribs & 19.7 & 20.2 & 18.5 & 19.9 & 22.7 & 0.58 & NS \\
\hline Bone & 5.4 & 5.2 & 5.0 & 5.1 & 5.6 & 0.20 & NS \\
\hline Lean & 9.5 & 10.5 & 9.7 & 10.6 & 12.0 & 0.29 & NS \\
\hline Subcutaneous fat & 2.4 & 2.0 & 2.0 & 2.0 & 1.9 & 0.17 & NS \\
\hline Intramuscular fat & 1.9 & 1.9 & 1.3 & 1.7 & 2.5 & 0.17 & NS \\
\hline Flank & 8.9 & 8.8 & 8.4 & 9.4 & 8.9 & 0.22 & NS \\
\hline Bone & 1.7 & 1.8 & 2.2 & 1.9 & 1.9 & 0.08 & NS \\
\hline Lean & 3.1 & 3.3 & 3.3 & 3.6 & 3.4 & 0.12 & NS \\
\hline Subcutaneous fat & 2.4 & 2.1 & 1.6 & 2.2 & 2.2 & 0.12 & NS \\
\hline Intramuscular fat & 1.6 & 1.3 & 1.4 & 1.5 & 1.5 & 0.08 & NS \\
\hline Long leg & 46.6 & 46.2 & 47.4 & 46.8 & 44.7 & 0.36 & NS \\
\hline Bone & 7.5 & 7.1 & 8.8 & 8.7 & 7.7 & 0.28 & NS \\
\hline Lean & 25.8 & 27.0 & 27.4 & 27.3 & 25.9 & 0.40 & NS \\
\hline Subcutaneous fat & 9.3 & 8.1 & 7.4 & 6.6 & 7.9 & 0.45 & NS \\
\hline Intramuscular fat & 3.3 & 2.3 & 2.4 & 3.6 & 2.3 & 0.21 & NS \\
\hline
\end{tabular}

P - statistical significance: NS - non significant; SED - standard error difference of means

FR (2-24) - offering fresh feed every $2 \mathrm{~h}, 4 \mathrm{~h}, 8 \mathrm{~h}, 12 \mathrm{~h}$ and $24 \mathrm{~h}$, respectively 
Table 6 Effect of feed refreshing frequency on total carcass muscle, bone and fat ratios (\%) of lambs

\begin{tabular}{lccccccc}
\hline \multirow{2}{*}{ Parameters, \% } & \multicolumn{7}{c}{ Groups } \\
\cline { 2 - 8 } & FR2 & FR 4 & FR 8 & FR 12 & FR 24 & SED & P \\
\hline \multirow{2}{*}{ Lean } & 52.0 & 55.2 & 55.6 & 55.8 & 54.8 & 0.70 & NS \\
Bone & 20.4 & 20.3 & 21.9 & 21.1 & 20.9 & 0.36 & NS \\
Subcutaneous fat & 16.9 & 14.2 & 12.9 & 12.7 & 14.0 & 0.63 & NS \\
Intramuscular fat & 8.8 & 7.1 & 6.8 & 8.7 & 7.7 & 0.31 & NS \\
\hline
\end{tabular}

P - statistical significance: NS - non significant; SED - standard error difference of means

FR (2-24) - offering fresh feed every $2 \mathrm{~h}, 4 \mathrm{~h}, 8 \mathrm{~h}, 12 \mathrm{~h}$ and $24 \mathrm{~h}$, respectively

Carcasses were dissected, and muscle, bone and fat tissues were separated in each main part. Total carcass muscle, bone and fat ratios are given in Table 6. No statistical significant difference was observed among groups. It was expected that feed refreshing might increase muscle ratio in the experimental lambs, which could be attributed to protein deposition. Although frequency (two meals) increased growth performance, body protein and fat composition in fish (Türker, 2006), there is a lack of information on the performance of lambs under such conditions to be compared with the present results. Yang \& Varga (1989) fed dairy cows four times a day and found that an increased feeding frequency enhanced fat deposition. Increased feeding frequency of diets containing higher proportions of concentrate may improve ruminal fermentation and nutrient utilization. Feeding more frequently stabilized ruminal pH (Cecava et al., 1990) and provided more constant supplies of microbial fermentation end-product such as branched-chain volatile fatty acids, peptides and ammonia N. These changes could lead to improved efficiency of microbial growth (Cecava et al., 1990) and consequently, may stimulate daily gain and protein deposition.

\section{Conclusion}

The present study showed that an increased feed refreshing frequency stimulated feed intake and daily gain without affecting carcass characteristics. Growth performance results showed that FR2 lambs gained almost $2.6 \mathrm{~kg}$ more marketable body weight compared to the FR24 lambs, those subjected to the conventional ad libitum feeding method. More frequent feeding would increase labour costs, though fully automatic feeding systems should compensate for that.

\section{Acknowledgement}

Authors are thankful to the Scientific and Technological Research Council of Turkey (TUBITAK) for supporting the project with registration number VHAG-2027. This study was the animal performance part of this project.

\section{References}

Cecava, M.J., Merchen, N.R., Berger, L.L. \& Nelson, D.R., 1990. Effect of energy level and feeding frequency on site of digestion and postruminal nutrient flows in steers. J. Dairy Sci. 73, 2470-2479.

Colomer-Rocher, F., Morand-Fehr, P. \& Kirkton, A.H., 1987. Standard methods and procedures for goat carcass evaluation, jointing and tissue separation. Livest. Prod. Sci. 17, 149-159.

Demirören, E., 2002. Hayvan Davranışları (I. Basım), EÜ Ziraat Fakültesi Yayınları No, 547, Bornova, İzmir, Turkey. $278 \mathrm{pp}$.

Eliçin, A., İlaslan, M., Munzur, M., Cangir, S. \& Karabulut, A., 1983. Fattening performance of weaned lambs that pastured on the mixture of vetch and barley farmlands. Institute of Grassland and Animal Science, Ankara (in Turkish).

Forbes, J.M., 1995. Voluntary Food Intake and Diet Selection in Farm Animals, CAB International, Wallingford, UK. 532 p.

Fraser, A.F. \& Broom, D.M., 1990. Farm Animal Behaviour and Welfare, Third Ed., ELBS, London, UK. $437 \mathrm{p}$. 
Goetsch, A.L. \& Galyean, M.L., 1983. Influence of feeding frequency on passage of fluid and particulate markers in steers fed a concentrate diet. Can. J. Anim. Sci. 63, 727-730.

Keskin, M., Şahin, A., Biçer, O. \& Gül, S., 2004. Comparison of the behaviour of Awassi lambs in cafeteria feeding system with single diet feeding system. Appl. Anim. Behav. Sci. 85, 57-64.

Keskin, M., Şahin, A., Biçer, O., Gül, S., Kaya, Ş., Sarı, A. \& Duru, M., 2005. Feeding behaviour of Awassi sheep and Shami (Damascus) goats. Turk. J. Vet. Anim. Sci. 29, 435-439.

Liboux, S.L. \& Peyraud, J.L., 1999. Effects of forage particle size and feeding frequency on fermentation patterns and sites and extent of digestion in dairy cows fed mixed diets. Anim. Feed Sci. Technol. 76, 297-319.

McDonalds, P., Edwards, R.A., Greenhalgh, J.F.D. \& Morgan, C.A., 1995. Animal Nutrition, Fifth Ed., Longman Scientific \& Technical, New York. 607 p.

Merchen, N.R., 1988. Digestion, absorption and excretion in ruminants. In: The Ruminant Animal, Digestive Physiology and Nutrition. Ed. Church, D.C., New Jersey, USA. pp. 172-201.

NRC, 1985. Nutrient Requirements of Sheep, $60^{\text {th }}$ Rev. Ed., National Academy Press, Washington D.C., USA. 77 p.

Özen, N., 1995. Animal Nutritional Physiology and Metabolism. Akdeniz University Agriculture Faculty Lecture Notes, Antalya, Turkey. 343 pp. (in Turkish).

Priolo, A., Micol, D., Agabriel, J., Prache, S. \& Dransfield, E., 2002. Effect of grass or concentrate feeding systems on lamb carcass and meat quality. Meat Sci. 62, 179-185.

Santos-Silva, J., Bessa, R.J.B. \& Santos-Silva, F., 2002. Effect of genotype, feeding system and slaughter weight on the quality of light lambs, (I) growth, carcass composition and meat quality. Livest. Prod. Sci. 76, 17-25.

Shabi, Z., Arieli, A., Bruckental, I., Aharoni, Y., Zamwel, S., Bor, A. \& Tagari, H., 1998. Effect of the synchronization of the degradation of dietary crude protein and organic matter and feeding frequency on ruminal fermentation and flow of digesta in the abomasum of dairy cows. J. Dairy Sci. 81, 1991-2000.

Shabi, Z., Bruckental, I., Zamwell, S., Tagari, H. \& Arieli, A., 1999. Effects of extrusion of grain and feeding frequency on rumen fermentation, nutrient digestibility, and milk yield and composition in dairy cows. J. Dairy Sci. 82, 1252-1260.

Türker, A., 2006. Effects of feeding frequency on growth, feed consumption, and body composition in Juvenile turbot (Psetta maxima linnaeus, 1758) at low temperature. Turk. J. Vet. Anim. Sci. 30, 251-256.

Van den Borne, J.J.G.C., Verstegen, M.W.A., Alferink, S.J.J., Giebels, R.M.M. \& Gerrits, W.J.J., 2006. Effects of feeding frequency and feeding level on nutrient utilization in heavy preruminant calves. J. Dairy Sci. 89, 3578-3586.

Yang, C.M. \& Varga, G.A., 1989. Effect of three concentrate feeding frequencies on rumen protozoa, rumen digesta kinetics, and milk yield in dairy cows. J. Dairy Sci. 72, 950-957. 